\title{
PERSEPSI TENTANG USIA PERNIKAHAN PEREMPUAN DAN JUMLAH ANAK YANG DIHARAPKAN: MAMPUKAH MEMPREDIKSI PRAKTEK PENGASUHAN ORANG TUA?
}

\author{
Oktriyanto $^{1 *}$, Hilma Amrullah ${ }^{1}$, Dwi Hastuti ${ }^{2}$, Alfiasari $^{2}$ \\ ${ }^{1}$ Pusat Penelitian dan Pengembangan KB dan KS, Badan Kependudukan dan Keluarga Berencana Nasional, \\ JI. Permata 1 No.1 Jl. Halim Perdanakusuma, RT.4/RW.5, Kb. Pala, Makasar, Kota Jakarta Timur, Daerah \\ Khusus Ibukota Jakarta, 13650, Indonesia \\ ${ }^{2}$ Departemen IImu Keluarga dan Konsumen, Fakultas Ekologi Manusia, Institut Pertanian Bogor, \\ Bogor, 16680, Indonesia \\ "E-mail : oktriyanto@yahoo.com
}

\begin{abstract}
Abstrak
Di Indonesia, usia ideal menikah dan jumlah anak ideal telah menjadi isu dalam pembangunan keluarga. Penelitian ini bertujuan untuk menganalisis persepsi usia pernikahan perempuan dan keinginan jumah anak pada keluarga dengan anak usia prasekolah di Indonesia dan kemudian dikaitkan dengan praktek pengasuhan yang dilakukan. Data yang digunakan dalam penelitian adalah data sekunder dari Survei Indikator Kinerja Program Kependudukan, Keluarga Berencana dan Pembangunan Keluarga (KKBPK) Rencana Pembangunan Jangka Menengah Nasional (RPJMN) Tahun 2017. Responden dalam studi ini adalah ibu yang memiliki anak usia prasekolah, berjumlah 17.886 orang. Hasil penelitian menunjukan bahwa pengasuhan yang baik sejalan dengan karakteristik ibu seperti status ibu bekerja, usia ibu yang semakin dewasa, pendidikan ibu yang lebih tinggi, dan banyaknya jumlah anak prasekolah di dalam keluarga. Studi ini juga menunjukkan adanya hubungan antara pengasuhan yang baik dengan sikap ibu yang tidak setuju terhadap pernikahan perempuan di bawah 21 tahun dan juga sikap tidak setuju untuk memiliki anak lebih dari tiga. Temuan ini mengindikasikan bahwa penilaian ibu terkait usia pernikahan perempuan dan jumlah anak dapat memprediksi praktek pengasuhan yang diterapkan pada keluarga. Oleh karenanya, program peningkatan kapasitas pengasuhan perlu mempertimbangkan keyakinan ibu tentang usia pernikahan dan jumlah anak sebagai faktor yang berdampak terhadap praktek pengasuhan yang dilakukan.
\end{abstract}

Kata kunci: jumlah anak ideal, keluarga anak prasekolah, praktek pengasuhan, Survei Indikator KKBPK RPJMN BKKBN, usia ideal menikah

\section{Perception of The Marriage Age of Women and The Expected Number of Children: Could It Predict Parenting Practices?}

\begin{abstract}
In Indonesia, the ideal age for marriage and the number of ideal children has become an issue in family development program. This study aims to analyze the mother's perceptions of the marriage age of women and the expected number of children among families with preschool children in Indonesia and its relation to the practice of parenting. The study used secondary data from the Survey of Population, Family Planning and Family Development Program Performance, National Medium Term Development Plan Year 2017. Respondents of this study were mothers who had preschool children that were 17,886 people. The results showed that good parenting was in line with maternal characteristics such as the status of working mothers, increasingly mother's age, higher maternal education, and the number of preschoolers in the family. This study also showed that there is a relationship between parenting practices and the mother's attitude on the age marriage of women and the expected number of children. These findings indicate that maternal assessment of the age of marriage of women and the expected number of children could predict parenting practices carried out by the family. Therefore, the program to increase parenting capacity needs to consider the mother's beliefs about the age of marriage and the number of children as factors that will influence the parenting practices of the family.
\end{abstract}

Keywords: ideal number of children, ideal age for marriage, parenting practices, preschoolers family, Survey of Indicator KKBPK RPJMN BKKBN

\section{PENDAHULUAN}

Kehidupan keluarga pernikahan. Dalam dimulai dari membentuk sebuah sebuah pernikahan, tentu diperlukan kesiapan menikah dari masing-masing individu (Krisnatuti \& Oktaviani, 2010). Kesiapan menikah dipengaruhi oleh beberapa faktor seperti 
kesiapan emosi, finansial, spiritual, dan kematangan usia (Sari \& Sunarti, 2013). Usia individu khususnya perempuan pada saat memulai sebuah pernikahan menjadi hal yang menarik untuk diperhatikan. Usia perempuan saat pertama kali menikah dapat dijadikan sebagai indikator lama sekolah dan partisipasi kerja (Rohmah, 2013). Dalam kehidupan keluarga, usia menikah pertama kali bagi perempuan akan menentukan kualitas kehidupan keluarga yang akan dibentuk. Perempuan yang menikah terlalu dini, bahkan di usia anak-anak akan memperbesar resiko terganggunya kesehatan dan kesejahteraan perempuan dalam memasuki kehidupan keluarga (United Nations Population Fund, 2012).

Di Indonesia, usia ideal menikah yang dianjurkan pemerintah dalam hal ini BKKBN yaitu 21 tahun untuk perempuan dan 25 tahun untuk laki-laki (BKKBN, 2017). Sementara itu, penelitian Rohmah (2013) menemukan bahwa sebagian besar perempuan di wilayah perdesaan menikah pada usia di bawah 20 tahun. Hal tersebut dikarenakan kurangnya pengetahuan tentang usia menikah, rendahnya pendidikan, serta status pekerjaan. Hal yang sama juga diungkapkan oleh Zwang (2014) yang menyatakan bahwa sebagian besar perempuan yang menikah pada usia dini adalah mereka yang berasal dari latar belakang keluarga yang memiliki kondisi ekonomi rendah. Alasan ekonomi serta harapan mencapai keamanan sosial dan finansial setelah menikah menyebabkan banyak orang tua mendorong anaknya untuk menikah di usia muda (Fadlyana \& Larasati, 2009). Oleh karenanya, tidak salah pendapat Mathur, Greene, \& Malhotra (2003) yang menyebutkan bahwa penyebab utama terjadinya pernikahan dini (usia anak) adalah kombinasi antara tradisi, kemiskinan, dan kurangnya kesempatan dalam mengakses sumber daya pembangunan.

Di samping fakta bahwa masih terdapat banyak perempuan yang menikah di usia muda, namun hal tersebut tidak sejalan dengan jumlah anak yang diharapkan. Zwang (2014) menyatakan bahwa saat ini perempuan mengharapkan lebih sedikit anak dikarenakan biaya hidup dan biaya untuk membesarkan anak-anak yang terus meningkat. Pernyataan ini didukung oleh hasil penelitian Oktriyanto, Puspitawati, dan Muflikhati (2015) yang menemukan bahwa telah terjadi perubahan nilai yang menyebabkan menurunnya jumlah anak yang diharapkan keluarga, baik di perdesaan maupun di perkotaan.
Perempuan yang memiliki persepsi positif terhadap kesiapan menikah cenderung memiliki atau mengharapkan jumlah anak yang lebih sedikit dibandingkan perempuan yang memiliki persepsi sebaliknya. Persepsi positif tersebut salah satunya adalah sikap terhadap kesuburan pranikah, pengetahuan mengenai alat kontrasepsi, serta pengetahuan terhadap penyakit seksual (Zwang, 2014). Selain itu, Zwang (2014) juga menyatakan bahwa persepsi tersebut mampu mewujudkan program keluarga, kesehatan, serta memengaruhi kebijakan dan kehidupan di dalam keluarga.

Menurut Schwarz, Schäfermeier, dan Trommsdorff (2005), nilai-nilai yang dimiliki perempuan, khususnya oleh ibu akan memengaruhi nilai dan tujuan ibu dalam membesarkan anak. Adapun tujuan dalam membesarkan anak secara positif ditandai dengan penerimaan ibu terhadap anakanaknya. Hal tersebut juga akan berkaitan dengan praktek pengasuhan ibu yang selanjutnya akan memengaruhi perkembangan anak. Menurut Sunderland (2016), pengasuhan yang baik dapat meningkatkan kecerdasan sosial anak seperti mampu berinteraksi dengan orang lain, bekerja dalam kelompok, serta memiliki rasa saling mengasihi. Pengasuhan yang baik adalah yang bersifat tegas dan responsif. Hal ini dibuktikan dalam penelitian Pasaribu, Hastuti, dan Alfiasari (2013) yang menemukan bahwa pengasuhan otoritatif (menerapkan aturan dan responsif terhadap anak) dapat memengaruhi karakter remaja, sedangkan gaya pengasuhan permisif (membebaskan anak / tidak tegas) yang dilakukan oleh ibu secara negatif memengaruhi karakter remaja. Beberapa penelitian lain juga telah membuktikan peran pengasuhan terhadap perkembangan anak (Hastuti, Alfiasari, \& Chandriyani, 2010; Latifah, Hastuti, \& Latifah, 2010; Elmanora, Hastuti, \& Muflikhati, 2015; Umasyah \& Alfiasari, 2016; Humaeda \& Alfiasari, 2016; Junianti, Hastuti, \& Alfiasari, 2016; Alfiasari \& Rachmawati, 2017; Berlianti et al., 2016). Hasil-hasil penelitian tersebut menegaskan pentingnya pengasuhan yang berkualitas, khususnya oleh ibu sebagai pengasuh utama.

Pentingnya faktor pengasuhan terhadap perkembangan anak telah diterima secara luas dan telah dibuktikan secara empiris dalam berbagai penelitian yang dilakukan selama dekade terakhir dan dalam beragam latar belakang keluarga. Oleh karenanya, menemukan faktor-faktor yang dapat memengaruhi praktek pengasuhan orang tua 
perlu dilakukan untuk dapat memberikan kontribusi empiris tentang kebutuhan pendidikan pengasuhan untuk orang tua dalam beragam program dan kegiatan di masyarakat. Penelitian sebelumnya telah menemukan bahwa perbedaan latar belakang pendidikan, jenis pekerjaan, besar pendapatan, serta harapan orang tua menjadi faktor yang menyebabkan pengasuhan orang tua terhadap anak berbeda pada masing-masing orang tua (Mufarika, 2014).

Dalam penelitian yang dilakukan Dewanggi, Hastuti, dan Herawati (2015), diketahui bahwa usia ayah dan ibu memiliki hubungan negatif dengan gaya pengasuhan yang diterapkan. Hal ini mengindikasikan bahwa usia ibu dapat memengaruhi cara ibu dalam mengasuh anakanak mereka. Beberapa penelitian lain juga telah menemukan bahwa beberapa faktor yang memengaruhi pengasuhan diantaranya usia anak dan pendidikan orang tua (Humaeda \& Alfiasari, 2016, Voluntir \& Alfiasari, 2014), pendapatan keluarga (Umasyah \& Alfiasari, 2016), usia orang tua (Utami, Hernawati, \& Alfiasari, 2016), kepribadian ibu (Hermawan \& Alfiasari, 2017), dan juga temperamen anak (Ramadhianti \& Alfiasari, 2017). Temuantemuan tersebut menegaskan variabel-variabel karakteristik keluarga, baik orang tua dan anak cukup berperan memengaruhi praktek pengasuhan yang dilakukan.

Dalam isu yang lebih makro, perubahanperubahan sosiodemografi yang terjadi dalam beberapa dekade di dunia juga turut memberikan andil dalam membentuk kehidupan keluarga masa depan. Dalam publikasinya, the Organisation for Economic Co-operation and Development (2011), mengidentifikasi empat faktor yang dapat memengaruhi kehidupan keluarga masa depan di tahun 2030. Keempat faktor tersebut adalah perubahan demografi, perubahan sosial dan kehidupan masyarakat, teknologi, dan ekonomi. Beberapa faktor perubahan demografi yang akan memengaruhi kehidupan keluarga diantaranya adalah proyeksi jumlah penduduk, fertilitas, usia harapan hidup, dan imigrasi. Jumlah anak yang diharapkan dapat memengaruhi proyeksi penduduk yang akan berdampak terhadap kehidupan keluarga.

Penelitian yang dilakukan Oktriyanto, Puspitawati, dan Muflikhati (2015), menemukan bahwa usia menikah pertama istri berpengaruh tehadap jumlah anak yang diharapkan. Usia menikah pertama istri di perdesaan cenderung lebih muda dibandingkan dengan di perkotaan. Hasil penelitian tersebut juga membuktikan bahwa jumlah anak yang diharapkan keluarga di perdesaan cenderung lebih banyak dibandingkan keluarga di perkotaan. Berdasarkan temuan penelitian tersebut maka menganalisis lebih lanjut tentang keterkaitan usia menikah perempuan dan jumlah anak dengan praktek pengasuhan perlu dilakukan.

Beberapa penelitian tentang pengasuhan pada keluarga Indonesia yang telah dijelaskan sebelumnya (Hastuti, Alfiasari, \& Chandriyani, 2010; Latifah, Hastuti, \& Latifah, 2010; Elmanora, Hastuti, \& Muflikhati, 2015; Umasyah \& Alfiasari, 2016; Humaeda \& Alfiasari, 2016; Junianti, Hastuti, \& Alfiasari, 2016; Alfiasari \& Rachmawati, 2017; Berlianti et al., 2016) dilakukan dalam skala contoh penelitian berukuran kecil. Penelitian untuk memotret praktek pengasuhan anak pada keluarga-keluarga di Indonesia dengan menggunakan skala data besar masih sangat jarang dilakukan. Oleh karenanya, memanfaatkan data Survei Indikator Kinerja Program Kependudukan, Keluarga Berencana dan Pembangunan Keluarga (KKBPK) Rencana Pembangunan Jangka Menengah Nasional (RPJMN) Tahun 2017 untuk dapat menemukan keterkaitan antara penilaian ibu tentang usia pernikahan dan jumlah anak yang diharapkan akan dapat memberikan gambaran yang lebih mewakili keluarga Indonesia. Selain menganalisis keterkaitan ketiga variabel tersebut maka potret praktek pengasuhan yang diterapkan keluarga Indonesia di perdesaan dan perkotaan juga akan bisa digambarkan melalui survey ini. Oleh karenanya, secara khusus, artikel ini disusun dengan tujuan untuk menganalisis praktek pengasuhan keluarga Indonesia menggunakan data Survei Indikator KKBPK RPJMN Tahun 2017 berdasarkan wilayah perdesaan dan perkotaan di Indonesia serta kaitannya dengan persepsi ibu tentang usia pernikahan perempuan dan keinginan jumah anak yang diduga akan mampu memprediksi praktek pengasuhan yang diterapkan.

\section{METODE}

Penelitian ini dilakukan untuk mengidentifikasi capaian program pembangunan keluarga di indonesia, khususnya mengenai praktek pengasuhan pada keluarga dengan anak usia prasekolah (0-6 tahun). Penelitian ini mengindentifikasi persepsi (belief) orang tua mengenai usia pernikahan perempuan dan keinginan jumlah anak di dalam praktek pengasuhan. Desain penelitian ini adalah cross sectional study. Pengumpulan data menggunakan teknik survei berskala nasional 
sebagai bentuk evaluasi terhadap pelaksanaan program Kependudukan, Keluarga Berencana dan Pembangunan Keluarga pada tahun 2017. Survei tersebut dilakukan untuk mengidentifikasi estimasi parameter pada tingkat provinsi dan nasional yang dilakukan dengan pendekatan klaster.

Contoh dari penelitian ini adalah keluarga yang memiliki anak berusia balita dan prasekolah (berusia 0-6 tahun), serta bertempat tinggal di wilayah klaster terpilih, yang seluruhnya berjumlah 20.354 orang. Kemudian dari jumlah tersebut dipillih menjadi 17.886 orang yang yang merupakan keluarga yang memiliki anak berusia 0-6 tahun dengan responden ibu. Adapun pengumpulan data dilakukan pada bulan Maret - April 2017. Contoh dipilih menggunakan tiga tahapan kerangka contoh. Pertama melakukan identifikasi data desa/ kelurahan di seluruh Indonesia yang dilengkapi dengan informasi klasifikasi urban (perkotaan)/ rural (perdesaan). Kedua, melakukan identifikasi klaster di desa/ kelurahan terpilih (lokasi klaster terpilih sama dengan lokasi klaster pada Survei RPJMN 2016). Terakhir, melakukan identifikasi hasil listing rumah tangga di klaster terpilih.

Data yang digunakan adalah data sekunder. Data tersebut merupakan data dari hasil Survei Indikator Kinerja Program Kependudukan ,Keluarga Berencana dan Pembangunan Keluarga (KKBPK) Rencana Pembangunan Menengah Nasional (RPJMN) Tahun 2017. Data yang digunakan meliputi usia ibu, status pekerjaan ibu, pendidikan ibu, kuintil kekayaan, jumlah anak prasekolah, praktek pengasuhan, penilaian terhadap usia menikah perempuan, dan penilaian terhadap jumlah anak yang diharapkan. Seluruh data dalam penelitian ini diperoleh menggunakan alat bantu kuesioner, serta melalui proses wawancara yang dilakukan oleh enumerator kepada ibu.

Instrumen / alat ukur dalam penelitian ini disusun dan dikembangkan oleh tim BKKBN. Variabel praktek pengasuhan dalam penelitian ini terdiri dari tiga dimensi pengukuran yaitu aspek pengasuhan perkembangan fisik (tujuh butir pernyataan), aspek pengasuhan perkembangan jiwa / mental / spiritual (enam butir pernyataan), dan aspek pengasuhan perkembangan sosial (empat butir pernyataan). Variabel ini memiliki skala jawaban $\mathrm{Ya}=1$ dan Tidak $=0$. Pernyataan pada variabel praktek pengasuhan akan dijawab "Ya" oleh responden jika responden melakukan pernyataan tersebut kepada anak prasekolahnya, sebaliknya jika tidak melakukannya maka dijawab "Tidak".
Variabel pengasuhan dalam peneltian ini dihitung berdasarkan indeks total ketiga aspek yang dilakukan dengan metode pembobotan. Masing-masing pertanyaan memiliki nilai/bobot yang berbeda-beda yaitu antara 1, 2 dan 3 . Pada aspek pengasuhan fisik pertanyaan "anak diukur tinggi dan berat badannya", dan "anak diajari berperilaku hidup sehat" diberikan nilai 1. Sementara itu, pertanyaan "anak diimunisasi" dan "anak diobati jika sakit" diberi nilai 2. Pertanyaan "anak diberi makanan bergizi", "anak diberi ASI" dan "anak diberi vitamin" diberi nilai 3.

Selanjutnya, pada aspek pengasuhan perkembangan jiwa/ mental/ spiritual, pemberian nilai 1 diberikan pada pertanyaan "menemani anak bermain", "menemani anak belajar", dan "mengajari anak mengucapkan terima kasih". Sementara nilai 2 diberikan untuk pertnyaan "orang tua sebagai teladan/panutan" dan "mengajari anak untuk menghormati/ menghargai orang lain". Selanjutnya, untuk nilai 3 diberikan pada pertanyaan "menstimulasi/memacu kratifitas anak" dan "mengajari anak beribadah".

Pada aspek pengasuhan perkembangan sosial, pertanyaan "anak diikutkan lomba" diberi nilai 1. Sementara itu nilai 2 diberikan pada pertanyaan "memberi kesempatan bermain dengan teman sebaya" dan "anak dikursuskan". Selanjutnya, untuk pertanyaan "anak disekolahkan dan anak diikutkan PAUD" diberikan nilai 3 .

Adapun variabel penilaian ibu terhadap usia menikah pada perempuan dan variabel penilaian ibu terhadap jumlah anak yang diharapkan di dalam keluarga pada penelitian ini masing-masing terdiri dari satu pertanyaan. Pada masing-masing pertanyaan terdapat lima pilihan jawaban yaitu sangat setuju, setuju, netral, tidak setuju, dan sangat tidak setuju. Selanjutnya, dalam proses pengolahan data, skala pertanyaan tersebut dikelompokan menjadi dua pilihan saja. Responden yang menjawab sangat setuju dan setuju dikelompokan menjadi "setuju" $=1$. Adapun untuk jawaban netral, tidak setuju, dan sangat tidak setuju dikelompokan menjadi jawaban "tidak setuju" $=0$. "Setuju" dalam variabel penilaian ibu terhadap usia menikah bermakna "Ibu setuju dengan usia menikah <21 tahun" sedangkan pada variabel penilaian ibu terhadap jumlah anak bermakna "'Ibu setuju dengan jumlah anak $>3$ anak".

Selanjutnya, berdasarkan jawaban yang diberikan responden terhadap penilaiannya 
pada usia pernikahan perempuan berdasarkan pertanyaan yang diberikan, penelitian ini menetapkan dua kategori ibu, yaitu yang setuju dengan pernikahan dini pada perempuan, dengan pernikahan di bawah usia 21 tahun dan ibu yang tidak setuju terhadap hal tersebut. Demikian pula dengan penilaian ibu terhadap jumlah anak yang diharapkan di dalam keluarga. Penelitian ini mengkategorikan ibu menjadi dua, yaitu ibu yang setuju dengan jumlah anak lebih dari tiga (jumlah anak banyak) dan jumlah anak kurang dari tiga (jumlah anak sedikit).

Pengolahan data dilakukan mulai dari tahap data editing, coding, scoring, entering, cleaning, analyzing, dan interpreting. Pemberian skor pada variabel penelitian untuk pengolahan data pada variabel praktek pengasuhan, penilaian ibu terhadap usia pernikahan dan jumlah anak dibuat secara konsisten dalam bentuk indeks, yaitu mentransformasikan nilai skor variabel ke dalam interval $0-100$. Data dianalisis secara statistik deskriptif dan inferensia dengan menggunakan Microsoft Excel dan SPSS. Analisis deskriptif mencakup nilai rata-rata, nilai maksimum dan minimum pada data kuantitatif. Analisis inferensia yang digunakan yaitu uji hubungan untuk menemukan keterkaitan antara praktek pengasuhan dengan penilaian ibu terhadap usia pernikahan dan jumlah anak yang diharapkan di dalam keluarga.

\section{HASIL}

\section{Karakteristik Responden}

Hasil survei menemukan bahwa secara keseluruhan di kedua wilayah perdesaan dan perkotaan, usia ibu tersebar dari 15-78 tahun. Apabila dilihat berdasarkan jenjang pendidikan yang pernah diduduki ibu, hasil survei menunjukkan 61,6 persen ibu di perkotaan telah berhasil menempuh wajib pendidikan sembilan tahun, sedangkan di perdesaan persentasenya hanya sebesar 34,1 persen. Adapun lebih dari setengah ibu di perdesaan $(70,9 \%)$ dan di perkotaan $(71,5 \%)$ berstatus sebagai ibu rumah tangga.

Keluarga di Indonesia umumnya hidup dalam keluarga yang utuh. Hal ini terbukti bahwa lebih dari sembilan puluh persen responden di perdesaan dan di perkotaan hidup dalam keluarga utuh. Di sisi lain perbedaan yang cukup signifikan terlihat pada besar persentase kuintil kekayaan antara keluarga di perdesaan dan di perkotaan. Di perdesaan, sebesar 52,3 persen responden tergolong dalam keluarga dengan kuintil kekayaan rendah (terbawahmenengah kebawah), sedangkan di perkotaan hanya terdapat 17,6 persen saja.

Apabila melihat kepemilikan jumlah anak prasekolah, didapatkan hasil bahwa sebagian besar ibu hanya memiliki satu anak usia prasekolah di dalam keluarganya. $\mathrm{Di}$ perdesaaan ibu yang memiliki satu anak prasekolah persentasenya sebesar 83,6 persen, sedangkan di perkotaan jumlahnya tidak jauh berbeda yaitu 81,8 persen. Meskipun begitu, temuan tersebut menunjukkan bahwa sekitar satu dari sepuluh ibu di Indonesia memiliki anak usia prasekolah di dalam keluarganya lebih dari satu.

\section{Penilaian Ibu terhadap Usia Pernikahan dan Penilaian lbu terhadap Jumlah Anak yang diharapkan di Dalam Keluarga}

Hasil penelitian ini tentang penilaian ibu terhadap usia pernikahan perempuan menunjukkan hasil yang berbeda-beda. Data yang tersaji pada Tabel 1 menunjukkan bahwa proporsi ibu yang menyatakan setuju $(36,7 \%)$ lebih kecil dibandingkan dengan ibu yang menyatakan sikap tidak setuju $(63,3 \%)$ terhadap usia pernikahan perempuan di bawah usia 21 tahun. Berdasarkan hasil survei, ditemukan bahwa persentase ibu yang setuju dengan pernikahan dini (di bawah usia 21 tahun) pada perempuan menunjukkan proporsi yang lebih tinggi di wilayah perdesaan $(40,9 \%)$ dibandingkan dengan di perkotaan $(30,0 \%)$. Temuan penelitian ini dapat dimaknai bahwa sekitar empat dari sepuluh ibu di perdesaan dan tiga dari sepuluh ibu di perkotaan setuju dengan perempuan yang menikah di bawah 21 tahun. Temuan ini juga menunjukkan bahwa proporsi ibu yang setuju bahwa perempuan sebaiknya menikah di atas usia 21 tahun sudah cukup tinggi di Indonesia.

Tabel 1 Sebaran responden berdasarkan sikap terhadap usia pernikahan perempuan dan jumlah anak di dalam keluarga

\begin{tabular}{|c|c|c|c|c|c|c|}
\hline \multirow{2}{*}{ Sikap } & \multicolumn{2}{|c|}{ Perdesaan } & \multicolumn{2}{|c|}{ Perkotaan } & \multicolumn{2}{|c|}{ Tota } \\
\hline & $\mathrm{n}$ & $\%$ & $\mathrm{n}$ & $\%$ & $\mathrm{n}$ & $\%$ \\
\hline \multicolumn{7}{|c|}{$\begin{array}{l}\text { Sikap terhadap Perempuan yang Menikah }<21 \\
\text { Tahun }\end{array}$} \\
\hline Setuju & 4526 & 40,9 & 2042 & 30,0 & \multirow{2}{*}{$\begin{array}{c}6568 \\
11318\end{array}$} & \multirow{2}{*}{$\begin{array}{l}36,7 \\
63,3\end{array}$} \\
\hline $\begin{array}{l}\text { Tidak } \\
\text { setuju }\end{array}$ & 6550 & 59,1 & 4768 & 70,0 & & \\
\hline \multicolumn{7}{|c|}{ Sikap terhadap Jumlah Anak yang diharapkan $>3$} \\
\hline Setuju & 7534 & 68,0 & 4035 & 59,3 & & \multirow{2}{*}{$\begin{array}{l}64,7 \\
35,3\end{array}$} \\
\hline $\begin{array}{l}\text { Tidak } \\
\text { setuju }\end{array}$ & 3542 & 32,0 & 2775 & 40,7 & & \\
\hline
\end{tabular}


Tabel 2 Sebaran karakteristik keluarga yang mempunyai sikap setuju dengan perempuan yang menikah $<21$ tahun dan jumlah anak yang diharapkan > $3(n=5.389)$

\begin{tabular}{|c|c|c|c|c|}
\hline \multirow{2}{*}{ Karakteristik lbu } & \multicolumn{2}{|c|}{ Perdesaan } & \multicolumn{2}{|c|}{ Perkotaan } \\
\hline & $\mathrm{N}$ & $\%$ & $\mathrm{~N}$ & $\%$ \\
\hline \multicolumn{5}{|l|}{ Usia } \\
\hline Min-max & \multirow{2}{*}{\multicolumn{2}{|c|}{$\begin{array}{c}16-78 \\
31,49 \pm 7,63\end{array}$}} & \multirow{2}{*}{\multicolumn{2}{|c|}{$\begin{array}{c}15-75 \\
31,85 \pm 7,12\end{array}$}} \\
\hline Rata-rata $\pm S D$ & & & & \\
\hline \multicolumn{5}{|l|}{ Pendidikan } \\
\hline $\begin{array}{l}\text { Tidak sekolah-SD- } \\
\text { SMP }\end{array}$ & 2814 & 74,5 & 789 & 49,0 \\
\hline $\begin{array}{l}\text { SMA-Perguruan } \\
\text { Tinggi }\end{array}$ & 964 & 25,5 & 822 & 51,0 \\
\hline \multicolumn{5}{|l|}{ Tipologi Keluarga } \\
\hline Keluarga tidak utuh & 119 & 3,1 & 43 & 2,6 \\
\hline Keluarga utuh & 3660 & 96,0 & 1569 & 97,4 \\
\hline \multicolumn{5}{|l|}{ Status Pekerjaaan } \\
\hline Tidak bekerja & 2807 & 74,3 & 1250 & 77,6 \\
\hline Bekerja & 971 & 25,7 & 361 & 22,4 \\
\hline \multicolumn{5}{|l|}{ Jumlah Anak } \\
\hline \multicolumn{5}{|l|}{ Prasekolah } \\
\hline Lebih dari satu & 107 & 18,7 & 317 & 19,7 \\
\hline Satu anak & 3071 & 81,3 & 1294 & 80,3 \\
\hline \multicolumn{5}{|l|}{ Kuintil Kekayaan } \\
\hline $\begin{array}{l}\text { Rendah (menengah } \\
\text { bawah) }\end{array}$ & 2164 & 57,3 & 374 & 23,2 \\
\hline $\begin{array}{l}\text { Tinggi (menengah } \\
\text { atas) }\end{array}$ & 1615 & 42,7 & 1237 & 76,8 \\
\hline
\end{tabular}

Hal yang sama juga terlihat pada sikap orang tua terhadap jumlah anak yang diharapkan di dalam keluarga (Tabel 1). Hasil penelitian menunjukkan bahwa di perdesaan, proporsi ibu yang menyetujui untuk memiliki anak lebih dari tiga adalah sebesar 68 persen, sedangkan di kota hanya 59,3 persen. Hasil tersebut menarik karena dengan slogan "Dua Anak Lebih Baik" yang sering disosialisasikan kepada masyarakat, survei ini menunjukkan bahwa proporsi ibu yang setuju dengan jumlah anak lebih dari tiga di dalam keluarga masih lebih besar dibandingkan dengan yang tidak setuju. Meskipun begitu, bila dikaitkan dengan program Pembangunan Keluarga di Indonesia, khususnya terkait dengan Pendewasaan Usia Pernikahan (PUP) yang mendorong perempuan untuk menikah di atas 21 tahun dan mendorong keluarga untuk lebih baik mempunyai dua anak saja maka terlihat bahwa ibu di perkotaan mempunyai proporsi yang lebih besar untuk setuju terhadap pernikahan di atas 21 tahun dan setuju untuk mempunyai dua anak saja di dalam keluarga (kurang dari tiga anak).

Temuan ini juga mengindikasikan bahwa kesadaran ibu di perkotaan untuk meningkatkan kualitas kehidupan keluarga yang lebih baik melalui pendewasaan usia pernikahan perempuan dan membatasi jumlah anak lebih tinggi dibandingkan dengan ibu di perdesaan.

Selanjutnya, penelitian ini mengolah data ibu yang menyatakan setuju dengan keduanya, yaitu setuju dengan perempuan yang menikah di bawah 21 tahun dan setuju dengan jumlah anak yang diharapakan lebih dari tiga. Pengolahan data yang dilakukan menemukan sebanyak 5.389 ibu $(30,13 \%)$ yang menyatakan sikap setuju dengan keduanya. Berdasarkan jumlah tersebut, didapatkan bahwa rata-rata usia ibu yang setuju dengan keduanya yaitu 31,49 tahun di perdesaan dan 31,85 tahun di perkotaan. Hasil lain juga menunjukkan bahwa sebesar 74,5 persen ibu di perdesaan yang setuju dengan perempuan yang menikah di bawah 21 tahun dan setuju dengan jumlah anak yang diharapakan lebih dari tiga, masih berada pada kategori jenjang pendidikan rendah antara tidak bersekolah-SDSMP. Sementara ibu di perkotaan yang setuju dengan keduanya, mempunyai proporsi tertinggi dengan pendidikan antara SMAPerguruan Tinggi (Tabel 2).

Selain itu, perbedaan juga terlihat pada kategori kuintil kekayaan antara ibu di perdesaan dan di perkotaan yang memiliki sikap setuju dengan pernikahan perempuan dibawah 21 tahun dan mengharapkan anak lebih dari tiga (Tabel 2). Di perdesaan, 57,3 persen ibu memiliki kuintil kekayaan yang terkategori rendah, sedangkan sebanyak 76,8 persen ibu di perkotaan memiliki kuintil kekayaan yang terkategori tinggi. Berdasarkan hasil survei, pada kelompok ibu yang setuju dengan keduanya, terlihat perbedaan persentase antara pendidikan dan kuintil kekayaan ibu di perdesaan dan di perkotaan.

Tabel 3 Nilai rata-rata dan standar deviasi indeks pengasuhan berdasarkan sikap terhadap pernikahan dini $\quad(<21$ tahun) pada perempuan

\begin{tabular}{|c|c|c|c|c|}
\hline \multirow[t]{2}{*}{$\begin{array}{l}\text { Praktek } \\
\text { Pengasuh- } \\
\text { an }\end{array}$} & \multicolumn{2}{|c|}{$\begin{array}{l}\text { Setuju dengan } \\
\text { Perempuan yang } \\
\text { Menikah }<21 \\
\text { Tahun }\end{array}$} & \multicolumn{2}{|c|}{$\begin{array}{c}\text { Tidak Setuju } \\
\text { dengan } \\
\text { Perempuan yang } \\
\text { Menikah <21 } \\
\text { Tahun }\end{array}$} \\
\hline & $\begin{array}{l}\text { Perde- } \\
\text { saan }\end{array}$ & $\begin{array}{l}\text { Perkota } \\
\text {-an }\end{array}$ & $\begin{array}{c}\text { Perdesa- } \\
\text { an }\end{array}$ & $\begin{array}{c}\text { Perkota } \\
\text { an }\end{array}$ \\
\hline $\begin{array}{l}\text { Peng- } \\
\text { asuhan } \\
\text { Total }\end{array}$ & $\begin{array}{c}54,26 \pm \\
21,19\end{array}$ & $\begin{array}{c}65,03 \pm \\
20,37\end{array}$ & $\begin{array}{c}67,65 \pm \\
20,77\end{array}$ & $\begin{array}{c}68,25 \pm \\
20,31\end{array}$ \\
\hline Fisik & $\begin{array}{c}83,03 \pm \\
20,61\end{array}$ & $\begin{array}{c}82,75 \pm \\
21,99\end{array}$ & $\begin{array}{c}83,87 \pm \\
21,82\end{array}$ & $\begin{array}{r}83,67 \pm \\
2061\end{array}$ \\
\hline Mental & $\begin{array}{c}58,34+ \\
32,61\end{array}$ & $\begin{array}{c}59,37 \pm \\
31,74\end{array}$ & $\begin{array}{c}63,84 \pm \\
31,93\end{array}$ & $\begin{array}{c}63,42 \pm \\
31,65\end{array}$ \\
\hline Sosial & $\begin{array}{c}51,42 \pm \\
27,83\end{array}$ & $\begin{array}{c}52,99_{ \pm} \\
27,76\end{array}$ & $\begin{array}{c}55,22 \pm \\
27,95\end{array}$ & $\begin{array}{c}57,67 \pm \\
27,99\end{array}$ \\
\hline
\end{tabular}


Tabel 4 Nilai rata-rata dan standar deviasi indeks pengasuhan berdasarkan sikap terhadap jumlah anak yang diharapkan di dalam keluarga

\begin{tabular}{|c|c|c|c|c|}
\hline \multirow{2}{*}{$\begin{array}{l}\text { Praktek } \\
\text { Pengasu- } \\
\text { han }\end{array}$} & \multicolumn{2}{|c|}{$\begin{array}{c}\text { Setuju dengan } \\
\text { Jumlah Anak yang } \\
\text { Diharapkan }>3\end{array}$} & \multicolumn{2}{|c|}{$\begin{array}{c}\text { Tidak Setuju } \\
\text { dengan Jumlah } \\
\text { Anak yang } \\
\text { Diharapkan > } 3\end{array}$} \\
\hline & $\begin{array}{c}\text { Perdesa } \\
\text {-an }\end{array}$ & $\begin{array}{c}\text { Perkota } \\
\text {-an }\end{array}$ & $\begin{array}{c}\text { Perdesa } \\
\text {-an }\end{array}$ & $\begin{array}{c}\text { Perkota } \\
\text {-an }\end{array}$ \\
\hline $\begin{array}{l}\text { Pengasuh } \\
\text {-an Total }\end{array}$ & $\begin{array}{c}65,60_{ \pm} \\
21,17\end{array}$ & $\begin{array}{c}66,90_{ \pm} \\
20,74\end{array}$ & $\begin{array}{c}67,68 \pm \\
20,60\end{array}$ & $\begin{array}{c}67,84 \pm \\
19,83\end{array}$ \\
\hline Fisik & $\begin{array}{c}82,99 \pm \\
22,46\end{array}$ & $\begin{array}{c}83,14 \pm \\
21,42\end{array}$ & $\begin{array}{c}84,68 \pm \\
21,57\end{array}$ & $\begin{array}{c}83,74 \pm \\
20,46\end{array}$ \\
\hline Mental & $\begin{array}{c}60,71 \pm \\
32,61\end{array}$ & $\begin{array}{c}61,91 \pm \\
32,11\end{array}$ & $\begin{array}{c}63,46 \pm \\
31,61\end{array}$ & $\begin{array}{c}62,64 \pm \\
31,17\end{array}$ \\
\hline Sosial & $\begin{array}{c}52,09_{ \pm} \\
27,91\end{array}$ & $\begin{array}{c}55,67 \pm \\
28,16\end{array}$ & $\begin{array}{c}54,89_{ \pm} \\
28,04\end{array}$ & $\begin{array}{c}57,13_{ \pm} \\
27,76\end{array}$ \\
\hline
\end{tabular}

Di sisi lain, tipologi keluarga, status bekerja, dan jumlah anak prasekolah menunjukan besar persentase yang tidak jauh berbeda antara ibu yang setuju dengan keduanya baik di wilayah di perdesaan maupun perkotaan. Hasil kajian ini menunjukkan bahwa lebih dari sembilan puluh persen ibu yang setuju dengan keduanya di perdesaan dan di perkotaan memiliki keluarga yang utuh. Adapun lebih dari setengah ibu yang setuju dengan keduanya di perdesaan dan di perkotaan berstatus tidak bekerja $(74,3 \%$ dan $77,6 \%)$ dan hanya memiliki satu anak usia prasekolah di dalam keluarga (81,3\% dan $80,3 \%)$.

Selanjutnya, Tabel 3 menyajikan hasil keragaan pengasuhan yang dilihat berdasarkan sikap ibu terhadap pernikahan dini pada perempuan. Di wilayah perdesaan, rata-rata indeks praktek pengasuhan secara keseluruhan lebih baik pada ibu yang menyatakan sikap tidak setuju $(67,65 \pm 20,77)$ dengan pernikahan dini dibandingkan yang menyatakan setuju $(54,26 \pm 21,19)$. Hal yang sama juga terlihat pada wilayah perkotaan, namun rata-rata indeksnya menunjukkan nilai yang tidak jauh berbeda antara ibu yang menyatakan sikap setuju $(65,03+20,37)$ dengan tidak setuju $(68,25 \pm 20,31)$. Dari ketiga aspek pengasuhan, aspek pengasuhan untuk perkembangan fisik memiliki nilai rata-rata indeks tertinggi, baik pada ibu yang setuju maupun tidak setuju dengan perempuan yang menikah <21 tahun. Di perdesaan, rata-rata indeks pengasuhan fisik pada ibu yang memiliki sikap setuju dengan pernikahan dini adalah sebesar 83,03+20,61.

Sementara pada ibu yang memiliki sikap tidak setuju adalah $83,87 \pm 21,82$. Rata-rata indeks tertinggi pada praktek pengasuhan mental terlihat pada ibu yang memiliki sikap tidak setuju dengan pernikahan dini di wilayah perdesaan $(63,42 \pm 31,65)$.

Berbeda halnya dengan rata-rata aspek pengasuhan sosial. Ibu di wilayah perkotaan yang memiliki sikap tidak setuju dengan pernikahan dini memiliki rata-rata indeks tertinggi yaitu 57,67 27,99 . Secara keseluruhan, baik di perdesaan maupun perkotaan dan juga berdasarkan setiap dimensi pengasuhan, hasil survei menunjukkan bahwa ibu yang memiliki sikap tidak setuju dengan pernikahan dini memiliki capaian indek pengasuhan yang lebih tinggi dibandingkan dengan ibu yang memiliki sikap setuju.

\section{Pengasuhan berdasarkan Sikap terhadap Jumlah Anak yang Diharapkan di Dalam Keluarga}

Hasil survei pada Tabel 4 menunjukkan bahwa praktek pengasuhan ibu berbeda berdasarkan sikapnya terhadap jumlah anak yang diharapkan. Di perdesaan, ibu yang mengharapkan anak lebih dari tiga memiliki rata-rata indeks pengasuhan fisik sebesar $82,99 \pm 22,46$, pengasuhan mental sebesar $60,71 \pm 32,61$, dan pengasuhan sosial sebesar $52,09 \pm 27,91$. Nilai tersebut lebih rendah dibandingkan di perkotaan yang menunjukkan capain rata-rata sebesar $83,14 \pm 21,42$ (fisik), $61,91 \pm 32,11$ (mental), dan $55,67 \pm 28,16$ (sosial).

Sementara itu, hasil survei menunjukkan bahwa ibu yang tidak setuju untuk memiliki lebih dari tiga anak memiliki rata-rata indeks pengasuhan yang cenderung lebih tinggi dibandingkan ibu yang setuju. Berdasarkan dimensi aspek pengasuhan, aspek fisik memiliki nilai rata-rata indeks tertinggi di antara dua aspek pengasuhan lainnya.

Di perdesaan ibu yang tidak mengharapkan memiliki lebih dari tiga anak memiliki pengasuhan fisik sebesar $84,68 \pm 21,57$, pengasuhan mental $63,46 \pm 31,61$, dan pengasuhan sosial $54,89 \pm 28,04$, Adapun di perkotaan ibu yang tidak mengharapkan memiliki lebih dari tiga anak memiliki pengasuhan fisik sebesar $83,74 \pm 20,46$, pengasuhan mental $62,64 \pm 31,17$, dan pengasuhan sosial $57,13 \pm 27,76$, Pada ibu yang tidak setuju atau tidak megharapkan memiliki lebih dari tiga anak, pengasuhan fisik dan mental terlihat lebih baik di wilayah perdesaan, sedangkan pengasuhan sosial lebih baik di perkotaan. 
Tabel 5 Koefisien uji hubungan antara variable bebas dengan pengasuhan keluarga Indonesia

\begin{tabular}{|c|c|c|c|}
\hline Variabel Bebas & Perdesaan & Perkotaan & $\begin{array}{l}\text { Perdesaan- } \\
\text { Perkotaan }\end{array}$ \\
\hline $\begin{array}{l}\text { Usia lbu (tahun) } \\
\text { Tipologi }\end{array}$ & 0,068 & 0,062 & 0,068 \\
\hline $\begin{array}{l}\text { Keluarga }(0= \\
\text { keluarga tidak } \\
\text { utuh, keluarga } \\
\text { utuh) }\end{array}$ & 0,019 & 0,011 & $0,016^{*}$ \\
\hline $\begin{array}{l}\text { Pendidikan ibu } \\
(0=\text { tidak lulus } \\
\text { wajib belajar } 9\end{array}$ & $0.115^{* *}$ & $0.105^{* *}$ & $0.112^{* *}$ \\
\hline $\begin{array}{l}\text { tahun, } 1=\text { lulus } \\
\text { wajib belajar } 9 \\
\text { tahun) }\end{array}$ & & & \\
\hline $\begin{array}{l}\text { Status Bekerja } \\
(0=\text { tidak } \\
\text { bekerja, } 1=\end{array}$ & $0,089^{* *}$ & $0,081^{* *}$ & $0,085^{* *}$ \\
\hline bekerja) & & & \\
\hline $\begin{array}{l}\text { Jumlah Anak } \\
\text { Prasekolah } \\
\text { Kuintil }\end{array}$ & $0,041^{* *}$ & $0,052^{* *}$ & $0,046^{* *}$ \\
\hline $\begin{array}{l}\text { Kekayaan } \\
(0=\text { menengah } \\
\text { bawah, } \\
1=\text { menengah } \\
\text { atas) }\end{array}$ & $0,104^{\star *}$ & $0,069^{* *}$ & $0,091^{* *}$ \\
\hline $\begin{array}{l}\text { Sikap terhadap } \\
\text { Pernikahan Dini } \\
\text { (indeks) }\end{array}$ & $0,077^{* *}$ & $0,078^{* *}$ & $0,079^{* *}$ \\
\hline $\begin{array}{l}\text { Sikap terhadap } \\
\text { Jumlah Anak di } \\
\text { Dalam Keluarga } \\
\text { (indeks) }\end{array}$ & $0,043^{* *}$ & 0,012 & $0,033^{* *}$ \\
\hline
\end{tabular}

\section{Hubungan antara Variabel Bebas dengan Praktek Pengasuhan}

Hasil uji hubungan antara karakteristik ibu, sikap ibu terhadap pernikahan dini, dan sikap terhadap jumlah anak yang diharapkan di dalam keluarga dengan pengasuhan ibu seperti yang tersaji pada Tabel 5 menunjukkan beberapa temuan yang menarik. Di perdesaan, usia $(r=0,068)$, pendidikan $(r=0,115)$, status bekerja $(r=0,089)$, kuintil kekayaan $(r=0,104)$, dan jumlah anak prasekolah $(r=0,041)$ berhubungan positif signifikan dengan pengasuhan ibu. Adapun di perkotaan faktor usia $(r=0,062)$, pendidikan $(r=0,105)$, status bekerja $(r=0,081)$, kuintil kekayaan $(r=0,069)$, dan jumlah anak prasekolah $(r=0,052)$ juga menunjukkan hubungan yang positif signifikan dengan pengasuhan ibu. Hal tersebut mengartikan bahwa pengasuhan yang baik berhubungan dengan usia ibu yang semakin bertambah, jenjang pendidikan ibu yang semakin tinggi, kuintil kekayaan yang semakin besar, dan juga jumlah anak usia prasekolah di dalam keluarga yang semakin bertambah. Adapun ibu yang bekerja juga mempunyai praktek pengasuhan yang lebih baik, baik di wilayah perdesaan maupun perkotaan. Temuan ini mengindikasikan bahwa faktor demografi seperti usia dan jumlah anak, faktor sosial seperti pendidikan dan status bekerja, dan juga faktor ekonomi yaitu kekayaan keluarga mampu menjelaskan keragaman praktek pengasuhan pada keluarga dengan anak usia prasekolah di Indonesia. Di daerah perdesaan dan perkotaan juga menunjukkan adanya hubungan positif signifikan tipologi keluarga $(r=0,016)$ dengan pengasuhan ibu. Hal ini menunjukkan bahwa peran ibu dalam pengasuhan baik dikeluarga utuh atau tidak utuh sangat dibutuhkan dan penting.

Hasil uji hubungan juga membuktikan bahwa sikap ibu terhadap pernikahan dini berhubungan positif signifikan dengan pengasuhan, baik di desa $(r=0,077)$, kota $(r=0,078)$, maupun secara keseluruhan di Indonesia $(r=0,079)$. Hasil tersebut berarti bahwa semakin ibu menunjukkan sikap tidak setuju terhadap pernikahan dini maka pengasuhan ibu juga akan semakin baik. Hasil yang serupa juga terlihat pada uji hubungan antara pengasuhan dengan sikap ibu terhadap jumlah anak yang diharapkan, Keduanya menunjukkan hubungan yang positif signifikan di wilayah perdesaan, perkotaan, dan secara keseluruhan di indonesia dengan nilai korelasi secara berturut-turut sebesar $r=0,043, r=0,012$ dan $r=0,033$. Temuan tersebut menunjukkan bahwa semakin ibu menunjukkan sikap tidak setuju untuk memiliki anak lebih dari tiga di dalam keluarga maka pengasuhan ibu akan semakin positif atau semakin baik.

\section{PEMBAHASAN}

Pernikahan sejatinya memerlukan kesiapan yang matang dari berbagai aspek agar pernikahan tersebut nantinya mampu membangun keluarga yang sejahtera. Oleh karenanya, untuk dapat menciptakan kehidupan pernikahan yang lebih baik maka diperlukan kesiapan emosi, finansial, spiritual, dan kematangan usia untuk menjadikan seseorang siap dalam membangun pernikahan (Sari \& Sunarti, 2013). Hasil penelitian Tyas, Herawati dan Sunarti (2017) menunjukkan usia istri yang semakin matang akan membuat istri atau ibu memiliki pengalaman dan pengetahuan yang lebih banyak sehingga pelaksanaan tugas perkembangan keluarga dapat berjalan dengan optimal dan mencapai kepuasan pernikahan.

Salah satu aspek yang terpenting dalam mengukur kesiapan menikah adalah usia 
seseorang dalam memulai pernikahan. Menurut BKKBN (2017), usia ideal menikah untuk perempuan adalah 21 tahun dan laki-laki 25 tahun. Usia pertama menikah seseorang menjadi penting karena semakin dewasa usia seseorang maka pengetahuan mereka terhadap diri sendiri akan semakin baik. Selanjutnya, hal tersebut akan berdampak pada cara seseorang menentukan dan memperkirakan tujuan hidup setelah pernikahan. Di sisi lain, usia menikah menjadi penting karena hal ini juga akan berkaitan dengan kesuburan sesorang. Tingkat kesuburan pranikah mencapai puncak bagi perempuan yang berusia 18-20 tahun, sementara tingkat kesuburan perkawinan mencapai puncak pada usia 27-32 tahun (Zwang, 2004).

Hal tersebut dipertegas dengan apa yang diutarakan Hartoyo, Latifah, dan Mulyani (2011), bahwa dimensi kematangan seseorang berhubungan dengan jumlah anak yang lahir di dalam keluarga. Jumlah anak yang lahir akan berkaitan dengan keinginan / harapan keluarga, khususnya ibu terhadap jumlah anak yang ingin dimiliki. Zwang (2004) mengungkapkan bahwa terdapat berbagai faktor yang memengaruhi jumlah anak yang diharapkan di dalam keluarga seperti fakor demografi dan nilai yang dimiliki oleh ibu. Nilainilai tersebut tentunya juga akan memengaruhi praktek pengasuhan yang dilakukan oleh ibu. Schwarz, Schäfermeier, dan Trommsdorff (2005) mengatakan bahwa pengasuhan secara khusus dipengaruhi oleh tujuan ibu yang berorientasi terhadap keluarga dalam membesarkan anak.

Survei ini secara khusus mengukur sikap ibu terhadap usia pernikahan pertama pada perempuan dan jumlah anak yang diharapkan ibu di wilayah Indonesia, baik di wilayah perdesaan maupun perkotaan. Hasil survei menunjukkan bahwa terdapat lebih banyak ibu di perdesaan dibandingkan dengan di perkotaan yang menunjukkan sikap setuju terhadap pernikahan perempuan di bawah 21 tahun dan setuju memiliki anak lebih dari tiga. Temuan ini menarik untuk disandingkan dengan hasil penelitian Rohmah (2013) yang menemukan bahwa usia menikah kebanyakan perempuan di desa adalah di bawah 20 tahun. Hasil survei ini menegaskan bahwa perempuan di wilayah perdesaan memang beresiko lebih tinggi untuk menikah dini, termasuk juga karena lebih banyak perempuan di perdesaan yang mempunyai sikap setuju terhadap pernikahan usia dini dibandingkan dengan perempuan di wilayah perkotaan Indonesia.
Hasil survei juga menunjukkan bahwa pada usia, pendidikan, kuintil kekayaan, status tidak bekerja/ibu, dan juga jumlah anak usia prasekolah di dalam keluarga berhubungan erat dengan praktek pengasuhan yang dilakukan keluarga dengan anak usia prasekolah di Indonesia, baik di perdesaan maupun perkotaan.

Mufarika (2014) menyatakan bahwa latar belakang seseorang seperti pendidikan, pekerjaan, besar pendapatan merupakan salah satu faktor yang memengaruhi pengasuhan orang tua terhadap anak. Sementara itu, dari segi pengasuhan, hasil survei secara keseluruhan menemukan bahwa nilai (indeks) pengasuhan ibu lebih baik pada ibu dengan sikap tidak setuju terhadap pernikahan perempuan di bawah usia 21 tahun dan juga lebih baik pada ibu yang tidak setuju dengan jumlah anak lebih dari tiga. Sementara itu, apabila dilihat berdasarkan aspek pengasuhan, aspek pengasuhan fisik memiliki capaian indeks tertinggi di antara aspek mental dan sosial.

Hasil uji hubungan menunjukkan pengasuhan yang baik sejalan dengan usia ibu yang semakin dewasa, jenjang pendidikan ibu yang semakin tinggi, dan kuintil kekayaan yang semakin besar. Selain hal tersebut, ibu yang bekerja dan jumlah anak prasekolah yang semakin banyak juga berkaitan dengan pengasuhan yang semakin baik. Temuan ini didukung dengan pernyataan Zwang (2014) bahwa latar belakang keluarga seperti halnya kondisi ekonomi yang rendah menyebabkan besar perempuan menikah pada usia muda / belum matang. Schumm \& Newsom (2016) juga mengungkapkan bahwa di negara-negara Barat, status sosial ekonomi dan capaian pendidikan yang rendah secara umum akan berkaitan dengan usia yang lebih dini / muda saat menikah.

Adapun secara keseluruhan, survei ini membuktikan adanya hubungan antara pengasuhan yang baik dengan sikap ibu terhadap pernikahan perempuan di bawah 21 tahun dan jumlah anak yang diharapkan, Dengan kata lain, sikap ibu yang tidak setuju denan pernikahan perempuan di bawah 21 tahun dan tidak setuju memiliki anak lebih dari tiga mampu memprediksi praktek pengasuhan yang lebih baik. Hasil ini didukung dengan nilai indeks pengasuhan yang lebih tinggi pada ibu yang bersikap tidak setuju dengan pernikahan perempuan di bawah 21 tahun dan memiliki anak lebih dari tiga. Hasil ini konsisten, baik di wilayah perdesaan maupun perkotaan. 
Sementara itu, berdasarkan tiga aspek pengasuhan, indeks ketiganya secara konsisten juga menunjukkan hasil yang lebih tinggi pada ibu yang tidak setuju dengan pernikahan perempuan di bawah 21 tahun dan tidak setuju dengan jumlah anak lebih dari tiga, dibandingkan ibu yang bersikap sebaliknya. Menurut Keller, Völker dan Yovsi (2005), pengasuhan yang berbeda pada tiap orang tua disebabkan oleh perbedaan pengalaman dan cara pengasuhan itu sendiri, yang nantinya juga akan memberikan efek yang berbeda pada kemampuan tumbuh kembang anak.

Oleh karenanya, beberapa penelitian yang terdahulu yang telah membuktikan secara konsisten peran pengasuhan terhadap tumbuh kembang anak dan ditambah dengan hasil temuan dari survei ini maka pengembangan program-program pendidikan pengasuhan pada keluarga-keluarga di Indonesia harus terus diperbaiki. Berdasarkan hasil penelitian ini, salah satu yang dapat dilakukan untuk dapat membangun kompetensi pengasuhan keluarga Indonesia yang lebih baik adalah terus meningkatkan sikap positif khususnya pada perempuan untuk mencegah pernikahan dini. Pendidikan bagi perempuan untuk mempersiapkan kehidupan pernikahan yang lebih baik, khususnya kematangan usia yang mencerminkan kematangan biologis dan psikologis perlu terus digalakkan. Selain itu, hasil penelitian ini juga membuktikan bahwa beban pengasuhan keluarga akan semakin bertambah dengan bertambahnya jumlah anak. Oleh karenanya, program untuk mengatur jarak dan jumlah kelahiran perlu disinkronkan dengan program edukasi pengasuhan. Mengingat temuan dalam survei ini menemukan masih banyaknya ibu yang lebih setuju terhadap jumlah anak lebih dari tiga namun dari uji hubungan menemukan bahwa pengasuhan ibu akan lebih baik jika anak di dalam keluarga kurang dari tiga.

\section{SIMPULAN DAN SARAN}

Hasil penelitian secara keseluruhan menunjukkan bahwa sebagaian besar responden ibu memiliki keluarga yang utuh, berstatus sebagai ibu rumah tangga, serta hanya memiliki satu anak prasekolah di dalam keluarga, Adapun usia ibu menyebar antara 1578 tahun, Sementara itu, apabila melihat dari segi pendidikan dan kuintil kekayaan, hasilnya lebih tinggi pada kelompok ibu di wilayah perkotaan. Hasil pengukuran mengenai sikap ibu terhadap pernikahan usia dini menunjukkan bahwa tidak lebih dari 50 persen ibu yang menunjukkan kesetujuan terhadap hal tersebut.
Meskipun pada kenyataanya, terlihat bahwa lebih besar persentase ibu di perdesaan dibandingkan ibu di perkotaan yang setuju dengan pernikahan perempuan di bawah 21 tahun. Hal ini secara tidak langsung menunjukkan bahwa sudah lebih banyak ibu yang paham mengenai usia pernikahan, Hal yang berbeda terlihat pada hasil penilaian ibu terhadap jumlah anak yang diharapkan di dalam keluarga. Secara keseluruhan, penelitian ini membuktikan bahwa pengasuhan cenderung lebih baik pada ibu yang menunjukkan sikap tidak setuju terhadap pernikahan usia dini, serta tidak mengharapkan untuk memiliki lebih dari tiga anak di dalam keluarganya. Hasil uji hubungan pada penelitian ini juga menunjukan ibu yang bekerja, usia ibu yang semakin dewasa, pendidikan ibu yang tinggi, dan banyaknya jumlah anak prasekolah di dalam keluarga sejalan dengan pengasuhan ibu yang semakin baik.

Hasil penelitian menunjukkan bahwa masih terdapat ibu yang setuju terhadap pernikahan perempuan di usia dini, serta setuju / mengharapkan memiliki lebih dari tiga anak di dalam keluarga. Di samping itu, hasil penelitian ini juga membuktikan bahwa pengasuhan yang baik justru sejalan dengan ibu yang menunjukkan ketidaksetujuan terhadap pernikahan dini dan memiliki lebih dari tiga anak. Oleh karena itu, perlu dilakukan upaya meningkatkan kesadaran ibu terhadap usia pernikahan dan jumlah anak yang ideal di dalam keluarga. Hal tersbeut juga mengindikasikan perlunya dilakukan upaya khususnya oleh pemerintah dalam menyosialisasikan mengenai usia pernikahan ideal dan pentingnya program KB bagi keluarga di Indonesia yang diintegrasikan dengan pendidikan pengasuhan.

\section{DAFTAR PUSTAKA}

Alfiasari., \& Rachmawati. (2017). Emotional socialization and emotional intelligence prevent aggressive behavior among school-age children in the rural family. Journal of Child Development Studies, 2(1), 12-22, doi: http://dx.doi.org/10.29244/jcds.2.1.12-22

Berlianti, D., Vitalaya, A., Hastuti, D., Sarwoprasojdo, S., \& Krisnatuti, D. (2016). Ada apa dengan komunikasi orang tua-remaja?: pengaruhnya terhadap agresivitas remaja pada sesama, Jurnal Ilmu Keluarga dan Konsumen, 9(3), 183-194, doi: 
http://dx.doi.org/10.24156/jikk.2016.9.3.1 83

BKKBN. (2017). Usia pernikahan ideal $21-25$ tahun. https://www.bkkbn.go.id Badan Keluarga BKKBN Usia Pernikahan Ideal 21-25

Tahun

https://www.bkkbn.go.id/detailpost/bkkbnusia-pernikahan-ideal-21-25-tahun.

Diakses Desember 2018

Dewanggi, M., Hastuti, D., \& Herawati, T. (2015). The influence of attachment and quality of parenting and parenting environment on children's character in rural and urban areas of Bogor. Jurnal IImu Keluarga \& Konsumen, 8(1), 20-27, doi:

http://dx.doi.org/10.24156/jikk.2015.8.1.2 0

Elmanora., Hastuti, D., \& Muflikhati, I. (2015). Kesejahteraan keluarga dan kualitas lingkungan pengasuhan pada anak usia prasekolah. Jurnal IImu Keluarga dan Konsumen, 8(2), 96-105, doi: http://dx.doi.org/10.24156/jikk.2015.8.2.9 6

Fadlyana, E., \& Larasati, S. (2009). Pernikahan usia dini dan permasalahannya. Sari Pediatri, 11(2): 136-140.

Hartoyo., Latifah, M., \& Mulyani, S. R. (2011). Studi nilai anak, jumlah anak yang diharapkan, dan keikutsertaan orang tua dalam program KB. Jurnal IImu Keluarga dan Konsumen, 4(1), 37-45, doi: http://dx.doi.org/10.24156/jikk.2011.4.1.3 7

Hastuti, D., Alfiasari., \& Chandriyani. (2010). Nilai anak, stimulasi psikososial, dan perkembangan kognitif anak usia 2-5 tahun pada keluarga rawan pangan di Kabupaten Banjarnegara, Jawa Tengah, Jurnal IImu Keluarga dan Konsumen, 3(1), 27-34, doi: http://dx.doi.org/10.24156/jikk.2010.3.1.2 7

Humaeda, N., \& Alfiasari. (2016). Analysis of children values, academic socialization, and motivation to continue Junior High School education. Journal of Child Development Studies, 1(2), 22-23, doi: http://dx.doi.org/10.29244/jcds.1.2.22-33

Ihromi, T. O. (1999). Bunga Rampai Sosiologi Keluarga. Yayasan Obor Indonesia,

Junianti, M. J., Hastuti, D., \& Alfiasari. (2016). Analisis sosialisasi akademik dan motivasi berprestasi anak usia sekolah pada keluarga di pedesaan. Jurnal Sekolah Dasar, 25(1), 1-11, doi: http://dx.doi.org/10.17977/um009v25i120 $16 \mathrm{p} 001$

Keller, H., Völker, S., \& Yovsi, R. D. (2005). Conceptions of parenting in different cultural communities: The case of West African Nso and Northern German women. Social Development, 14(1): 158180

Krisnatuti, D., \& Oktaviani, V. (2010). Persepsi dan kesiapan menikah pada mahasiswa. Jurnal IImu Keluarga dan Konsumen, 4(1), 30-36, doi: http://dx.doi.org/10.24156/jikk.2011.4.1.3 0

Latifah, E., Hastuti, D., \& Latifah, M. (2010). Pengaruh pemberian asi dan stimulasi psikososial terhadap perkembangan sosial-emosi anak balita pada keluarga ibu bekerja dan tidak bekerja. Jurnal IImu Keluarga dan Konsumen, 3(1), 35-45, doi:

http://dx.doi.org/10.24156/jikk.2010.3.1.3 5

Mathur, S., Greene, M., \& Malhotra, A. (2003). Too young to wed: the lives, rights, and health of young married girls. International Center for Research on Women. Washington DC: US. Diambil dari:

https://www.issuelab.org/resources/1142 1/11421.pdf

Mufarika, A. (2014). Pola pengasuhan anak pada keluarga miskin (studi kasus 5 keluarga miskin di Desa Kebontunggul Kecamatan Gondang Kabupaten Mojokerto). J+ PLUS UNESA, 3(1):1-11

Oktriyanto, O., Puspitawati, H., \& Muflikhati, I. (2015). Nilai anak dan jumlah anak yang diharapkan pasangan usia subur di wilayah perdesaan dan perkotaan. Jurnal IImu Keluarga \& Konsumen, 8(1), 1-9, doi:

http://dx.doi.org/10.24156/jikk.2015.8.1.1

Pasaribu, R. M., Hastuti, D., \& Alfiasari. (2013). Pengaruh gaya pengasuhan dan metode sosialisasi orang tua terhadap karakter jujur dan tanggung jawab siswa SMA di Kota Bogor. Jurnal IImu Keluarga dan Konsumen, 6(3), 163-171, doi: http://dx.doi.org/10.24156/jikk.2013.6.3.1 63 
Rohmah, N. (2013). Faktor-faktor yang memengaruhi usia perkawinan pertama wanita di Kecamatan Sidayu Kabupaten Gresik. Swara Bhumi, 2(1):97-107

Sari, F., \& Sunarti, E. (2013). Kesiapan menikah pada dewasa muda dan pengaruhnya terhadap usia menikah. Jurnal IImu Keluarga \& Konsumen, 6(3), 143-153, doi: http://dx.doi.org/10.24156/jikk.2013.6.3.1 43

Schumm, W. R., \& Newsom, K. C. (2016). Age at First Marriage, Encyclopedia of Family Studies. 1-3

Schwarz, B., Schäfermeier, E., \& Trommsdorff, G. (2005). Relations between value orientation, child-rearing goals, and parenting: A comparison of German and South Korean mothers

Sunderland, M. (2016). The Science of parenting: How today's brain research can help you raise happy, emotionally balanced children, Penguin
Tyas, F. P. S., Herawati, T., \& Sunarti, E. (2018). Tugas perkembangan keluarga dan kepuasan pernikahan pada pasangan menikah usia muda. Jurnal IImu Keluarga \& Konsumen, 10(2), 8394, doi: http://dx.doi.org/10.24156/jikk.2017.10.2. 83

Umasyah, R., \& Alfiasari. (2016). Effects of socialization methods and peer attachment on character strength of school-aged children. Journal of Child Development Studies, 1(2), 1-11, doi: http://dx.doi.org/10.29244/jcds.1.2.1-11

United Nations Population Fund. (2012). Marrying Too Young: End Child Marriage. United Nations Population Fund UNFPA, New York.

Zwang, J. (2004). Perceptions and attitudes towards late marriage and premarital fertility in rural South Africa. IFAS Working Paper Series/Les Cahiers de I'IFAS, 4: hal 61 